\title{
GEODESIC MONITORING DURING TEMPLE RESTORATION
}

\author{
Zakharchuk V., senior lecturer, \\ tzvvxxx@gmail.com, ORCID:0000-0002-0370-4113 \\ Tretenkov V., PhD, Professor, \\ Shishkalova N., Senior lecturer, \\ Shishkalova7@gmail.com \\ Odessa State Academy of Civil Engineering and Architecture
}

\begin{abstract}
During the construction and reconstruction of real estate and especially monuments of architecture, it is necessary to conduct geodetic monitoring. These are observations of the deformations of buildings during the construction process. Such monitoring allows you to determine the causes of deviations from the design and look ahead predicting their development, as well as provide recommendations and appropriate measures to prevent critical situations that can lead to irreparable consequences.

It is no secret that a new building after the completion of construction gives a draft for a certain time. This phenomenon is because the soil is compacted under the weight of a built house, so the draft of the property is considered to be completely a normal process.

Geodetic monitoring of the bell tower basement foundations of the Odessa saviour's Transfiguration Cathedral begins with a geometric leveling of the appropriate accuracy class using the level H3 and checkers slats. Before performing geodetic works, the level and checkers were tested to establish their suitability for this type of work. Geometric leveling was performed in the forward and reverse directions with the obligatory control of observations at each station.

Three ground rappers are attached to the territory with a reference to the initial riper a known mark of the city network. Measurements were taken not earlier than 10 days after the laying of signs.

Along the perimeter of the bell tower base fixed eight deformation were marked. The leveling of these marks was carried out from four stations, also tied to pre-fixed rappers. The results of the observations were recorded in accordance with fourteen cycles. The interval between the cycles of observations corresponds to a month.
\end{abstract}

The main work was aimed at studying the prediction of precipitation of deformation marks using statistical regularities with scheduling experimental and functional dependencies corresponding to the quadratic dependence of the form $\mathrm{H}=\mathrm{at} 2+\mathrm{bt}+\mathrm{c}$.

Key words: geodesic monitoring, deformation marks, geometric leveling, precipitation of the foundation, observation cycles, rapper, experimental and functional dependencies, forecast of subsidence of the basement of the bell tower.

Introduction. The term «building settlement» in the science of geodesy means decreasing some points of the built object, that causes inclination of the building, and in some cases its complete ruin. To avoid this, it's necessary to carry out geodesic monitoring to find out uniformity of the building points inclination. These operations are carried out not only for buildings which are in the process of construction or reconstruction, but also for buildings (constructions), which are located near the construction site.

The most important part of geodesic monitoring is geodesic observation of the building's deformations. They are carried out by using special geodesic devices, which allow to carry out geometric leveling procedure with maximum precision. To perform geodesic observation special benchmarks and lubber lines are applied along the entire perimeter of the object under the study. In each cycle of the calculations the difference of elevation points of these benchmarks is calculated. The acquired data allow to analyze deviations and the speed of their values change.

The geodetic control network of points and benchmarks plays and important part in the entire process. A very important moment should be taken into consideration: the points of the network

Вісник Одеської державної академії будівництва та архітектури, 2019. - Вип. № 75 
must be outside the area of settlement influence. Our land-surveyors carry out geodetic observations using innovative equipment - first-order levels. The allow obtaining peak precise data during the works performance.

The recent studies analysis. The Department of Engineering Geodesy at the Odessa State Academy of Civil Engineering and Architecture carries out on demand a constant geodetic monitoring of historical samples of architecture, including the period of reconstruction of outstanding historical houses of worship: The Saint Paul Cathedral of the German Evangelical Lutheran Church in Ukraine (The Kirchen) and the Transfiguration Cathedral [6].

Reconstruction of the Church with preservation of architectural value and the value of religious worship requires constant quantitative evaluation of spatiotemporal location of the adjusting constructions with the purpose of further forecasting behavior and suspense the further development of the deformations at their peak values to provide normal operation of those constructions with the purpose, if necessary, to take necessary action in time leading to saving samples of architecture and other buildings.

The aim and the task. Investigating the settlement of the bell-tower footing during building (reconstruction) of the main building of the saviour's Transfiguration Cathedral, which consists of two floors with gradual loading, and trial of the prediction theory of further settlement of the deformation benchmarks, which are set around the perimeter of the bell-tower's footing.

Materials and methods of the investigation. When in August 1794 solemn sanctification of Odessa city took place, the place of building of the Church named by St Nicholas the Wonderworker in the Sobornaya Square was sanctified. In 1795 the first stone was laid, and on the 18 of February 1800 the St Nicholas Temple was named the Cathedral. This temporary church was the ancestor of the future Cathedral.

Erection the temple started with the project of V. Vanrezant (Fig. 1) was renewed, supervision of the work was accredited to an architect Fr. Frapolli. Merchants of Odessa S. Androsov and I. Alekseev took part in the building of the Cathedral, and on the 20 of May 1808 they finished building of a new stone church - the main body of the Cathedral with the drum and a giant bell-tower. On the 25 of May 1808 an Archibishop Platon sanctified the main altar of the Cathedral in the name of the Transfiguration of Christ.

In 1825 (Fig. 2, 3) a project of the bell-tower developed by J. Frapolli was approved. The belltower was situated to the west of the Church. Building of the bell-tower was completed in 1837.

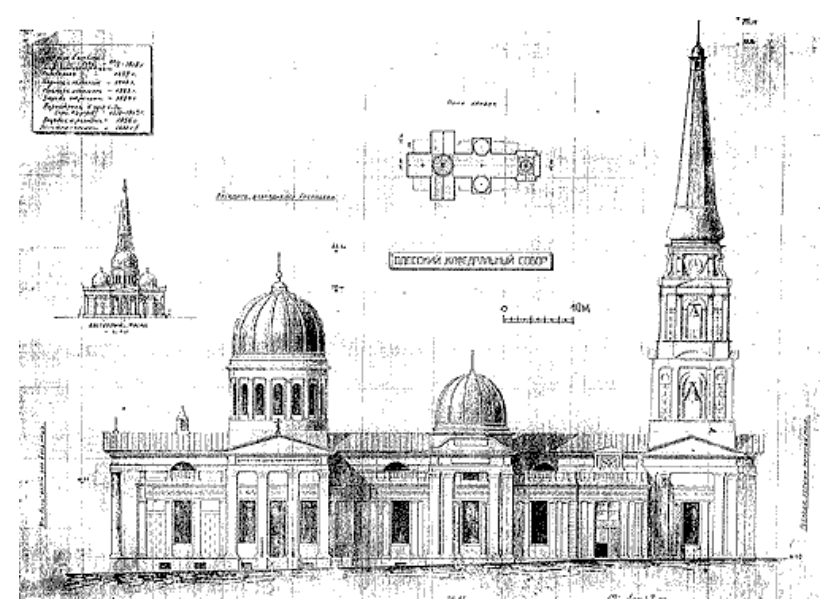

Fig. 1. Transfiguration Cathedral in Odessa. The project

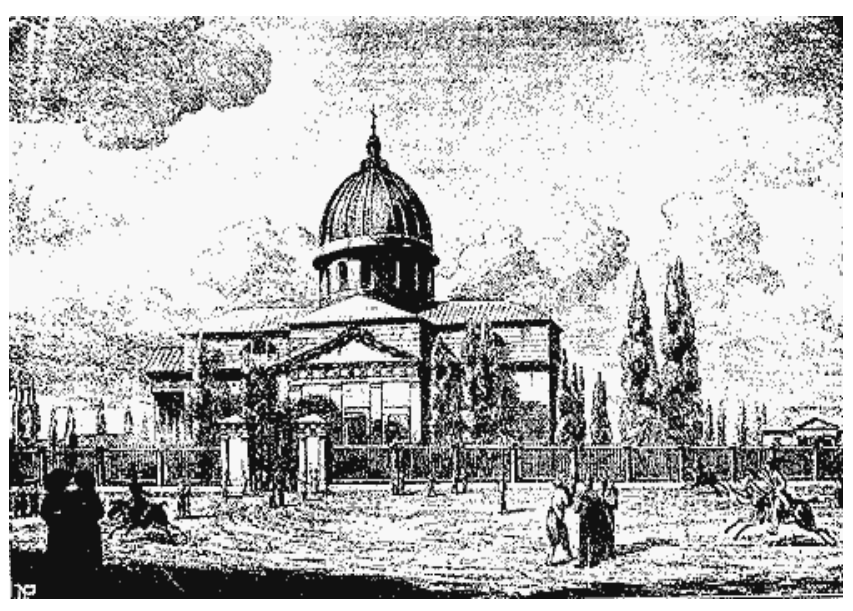

Fig. 2. The original look of the Cathedral without the bell-tower in the 20s of the XIX century. A reproduction

Taking into consideration that fact that in 1837 Odessa became eparchial Centre of Kherson Diocese. Transfiguration Cathedral became a Cathedral. It was a necessity in its expansion. On demand 
of the Archbishop of Kherson and Tavria Gavriil (Rozanov) in 1841 an architect D. Geidenreich made a project of a refectory, which combined the bell-tower and the old Church (Fig. 4, 5).

Partial reconstructions of the Cathedral were performed during the period between 1870 and 1880 years, and in 1894 the major repair of the Cathedral was performed (Fig. 6-8).

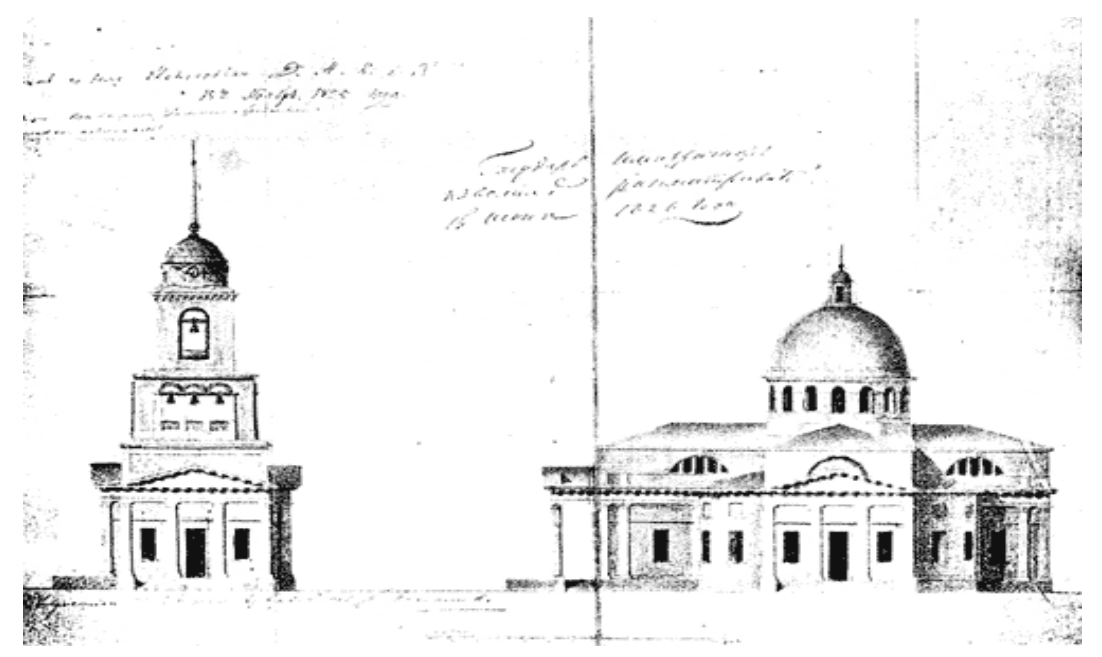

Fig. 3. The project of the 5-level bell-tower of the saviour's Transfiguration Cathedral of made in 1825 , the architect is F. M. Shesta
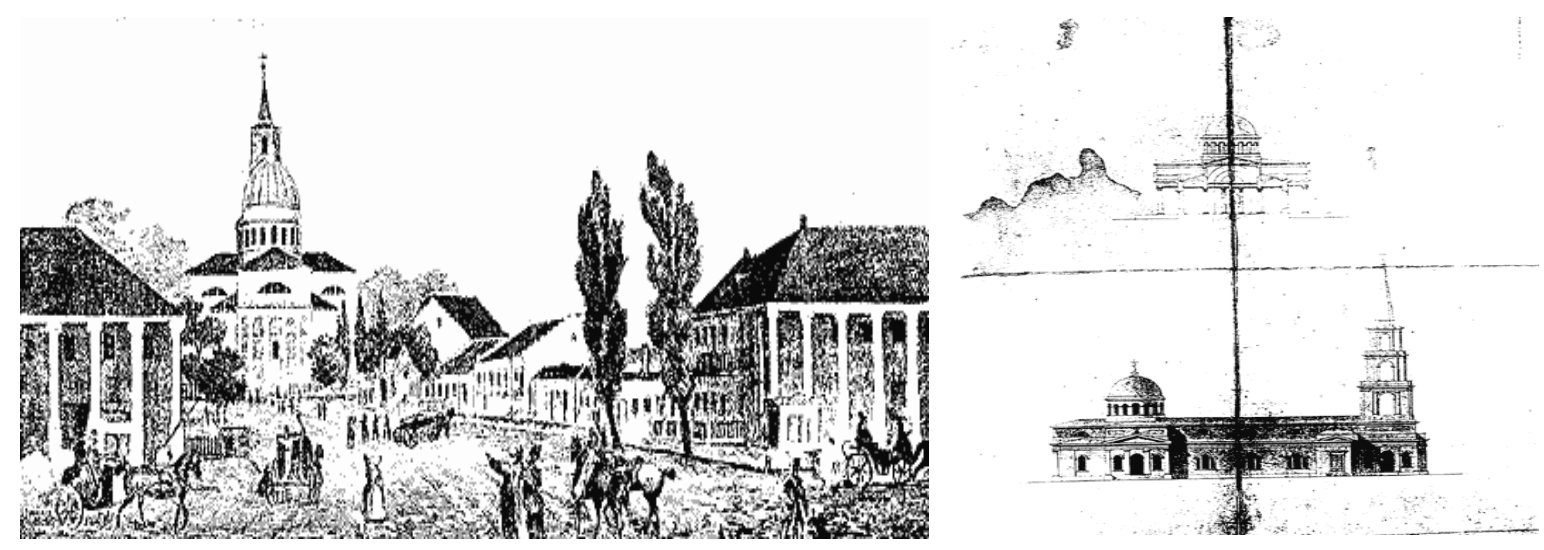

Fig. 4. The look of the saviour's

Transfiguration Cathedral from the Greek market in the 40s years of the XIXth century. Engraving

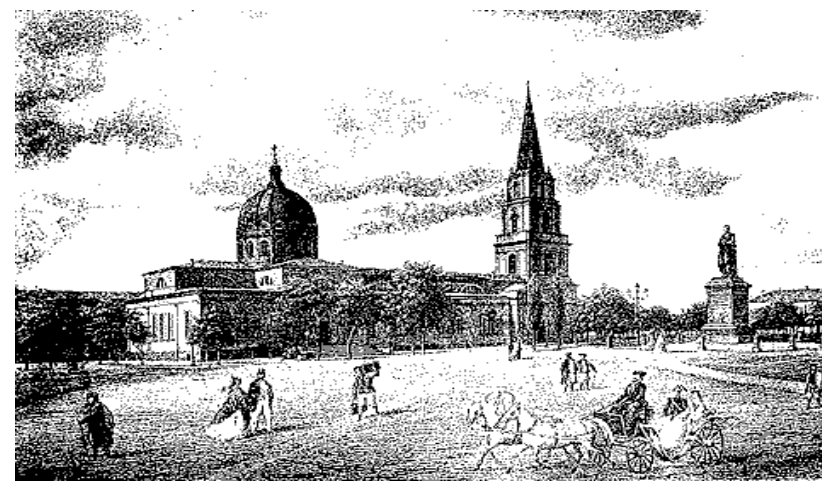

Fig. 6. Church of the saviour's Transfiguration Cathedral in 60-80s years of the XIXth century
Fig. 5. The project of the front and a sectional arrangement of the refectory of the saviour's Transfiguration Cathedral in 1841

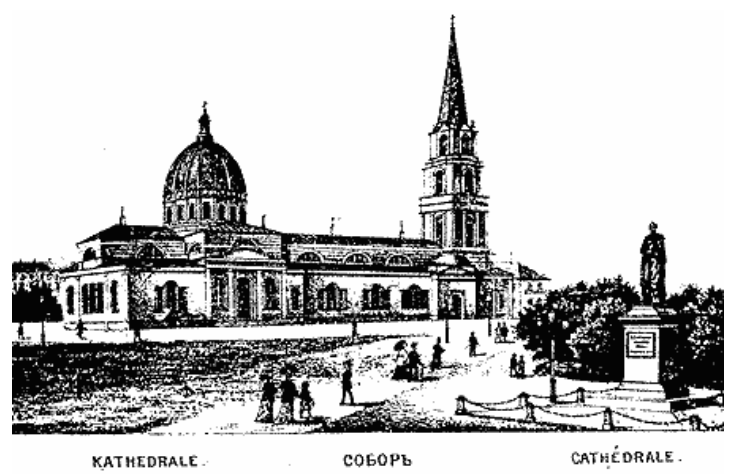

Fig. 7. Transfiguration Cathedral in 60-90s years of the XIXth century 


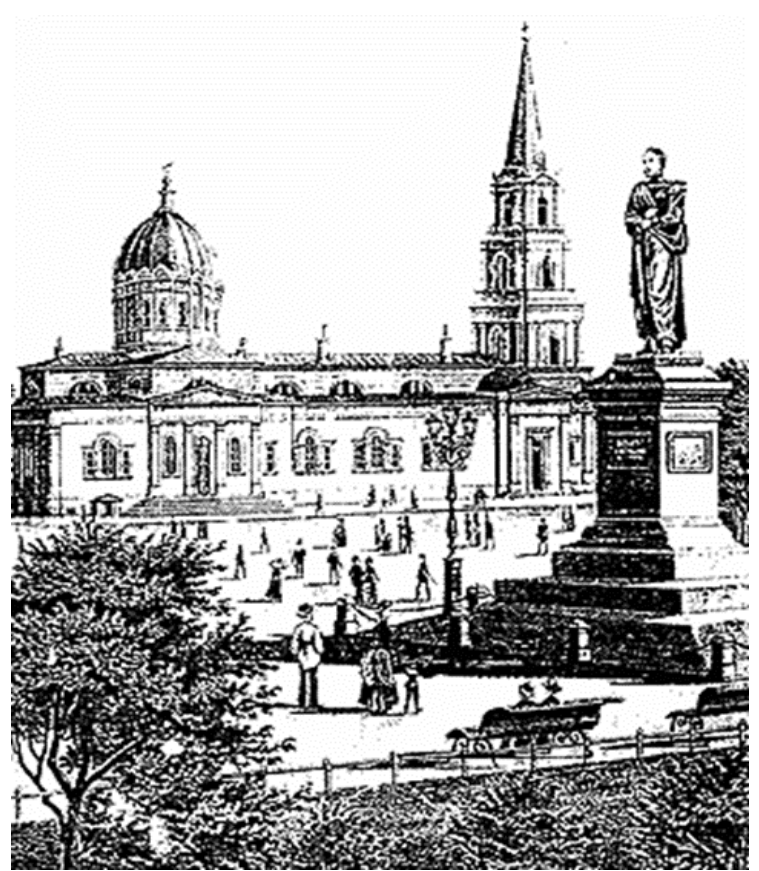

Fig. 8. Church of the saviour's Transfiguration Cathedral 80s years of the XIXth century

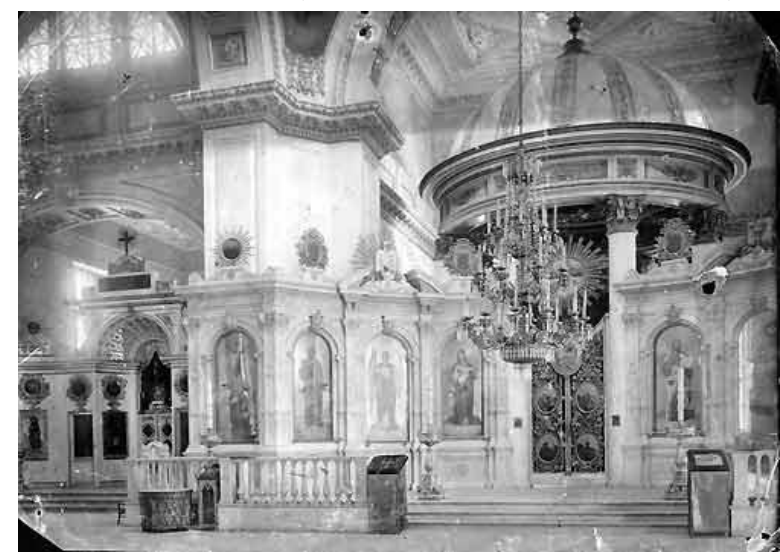

Fig. 9. The interior of the Cathedral after reconstruction in 1900-1903 years. The main

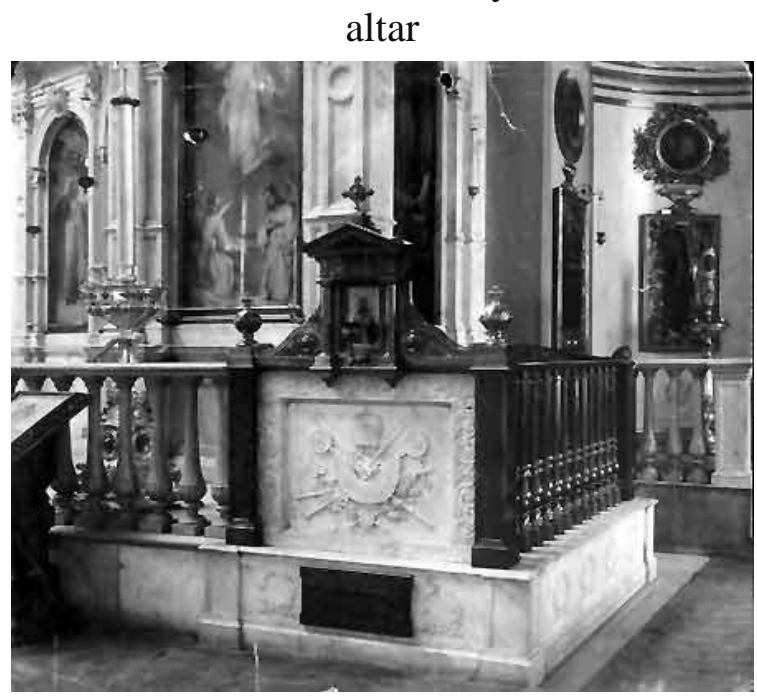

Fig. 10. The interior of the Cathedral after reconstruction in 1900-1903 years. The grave of duke Vorontsov
Architectural disadvantages of the Cathedral which appeared during numerous finishing buildings, were improved during the last reconstruction in 1900-1903, which cost 220 000 rubles that were spent from the municipal exchequer. The reconstruction intended not only change of the fronts, but also significant recon structuring of the interiors. During that period two side cupolas and a portico to the east front were built. The bell-tower was also decorated (Fig. 9-11).

The inside of the Cathedral was wonderful. The first thing that overwhelmed you at the entrance to the Church was a big amount of light and space. The columns in the interior in the Corinthian order were covered with artificial marble of white color. The floor was laid of white marble flagstones. A new iconostases was laid with greyish-white polished marble. Over the altar there was a domelike cover on its own columns. After reconstruction in 1903, the Cathedral became one of the biggest Churches in the Russian Empire and could admit up to 9000 people. Its measurements in the plan were $90 \times 45$ meters, and the height of the bell-tower was 72 meters.

In May 1936, the Cathedral was destroyed by the Bolshevistic authority. Before that it was robbed by the Soviet State, and the valuable things from the Cathedral were brought out on the lorries to Odessa Province Finance Department. Further destiny of the things taken away from the Cathedral is unknown.

Reconstruction of the Church was started in the 90s years. In 1996-1999 the excavations were performed and the old footing of the Cathedral was found. On the $5^{\text {th }}$ of September 1999 a ceremonial sanctification of the beginning of construction, and also a chamber with a message to future generations of Odessa and the hallows of St. George the Dragon Slayer was put into the basement of the Cathedral. On the $1^{\text {st }}$ of February 2000 the building of a zero cycle was started, and on the $29^{\text {th }}$ of April 2000 the first stone was laid into the footing of the bell-tower and sanctified.

Building the first part of the Cathedral the Bell-tower - took less than a year. At Christmas the $6^{\text {th }}$ of January 2001 in front of a big crowd of people, with the mellow chime of 14 bells, a ceremonial opening of the Bell-tower and sanctification of the Chapel at its first circle. 


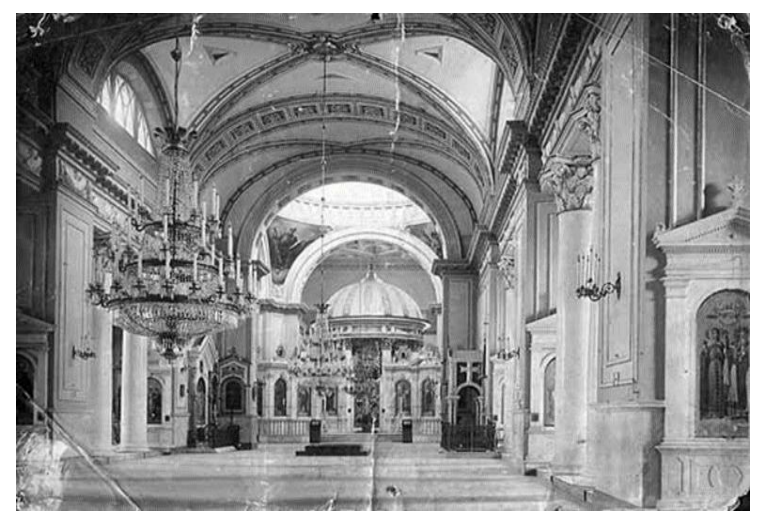

Fig. 11. The interior of the Cathedral after reconstruction in 1900-1903 years. The central nave

On the $19^{\text {th }}$ of January 2002 the first stone was laid into the wall of the upper Church of the Cathedral of the saviour's Transfiguration Cathedral.

The investigation results. Geodetic observation the settlement of the bell-tower footing was performed by fourteen cycles after the finishing of the building. Eight deformation benchmarks were set on the front and in the lower part of the building around the entire perimeter, which were under the observation for over a year. The places of the precise location of the benchmarks are fixed at the diagram of the belltower (Fig. 12).

Deformational benchmarks are the control geodetic benchmarks which are located on buildings and constructions for which the vertical movements were identified [2-5]. The observational interval is one month.

The observation of the deformational benchmarks was carried out by geometric leveling of the class III (Fig. 13), which is used with vertical moving of the footing base, according to the regulatory documents [4, section 10$]$ :

- Ukrainian national standardization system Б B.2.1-30:2014 «Types of soils. Methods of measurements deformations of buildings and constructions bases»;

- Ukrainian national construction regulation B.1.3-2:2010 «Geodetic works in building»; Changes №1 from 2018 to Ukrainian national construction regulation B.1.3-2:2010 «Assurance system of geometric specifications accuracy during construction. Survey operations in construction»; footings;

- Instruction on observation of deformations of buildings and constructions bases and

- Instruction on topographic filming in scales 1:5000, 1:2000, 1:1000 and 1:500;

- Instruction on geometric leveling of classes I-IV.

Geometric leveling of class III was performed with a leveling instrument H3 and checker rods. Before the work, the leveling instrument and leveling checker rods underwent investigation to identify their suitability for geometric leveling of the class III, conditioning and constant values definition $[4,5]$.

Geometric leveling was performed in the forward and backward direction. The control of the observation was carried out at each station, the difference between the exceedance value which were obtained on the black side and on the red side of the surveying rods, didn't exceed $3 \mathrm{~mm}$ considering the height difference of the couple of the rods.

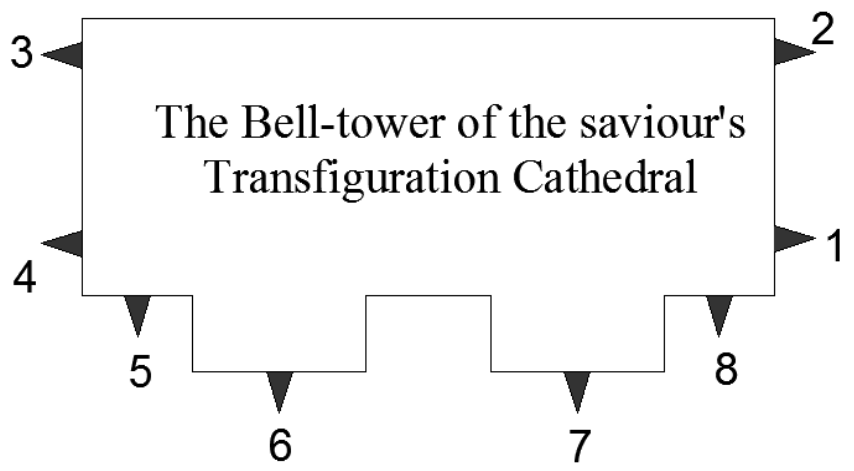

Fig. 12. The diagram of fixing deformational benchmarks on the bell-tower of the saviour's Transfiguration Cathedral 


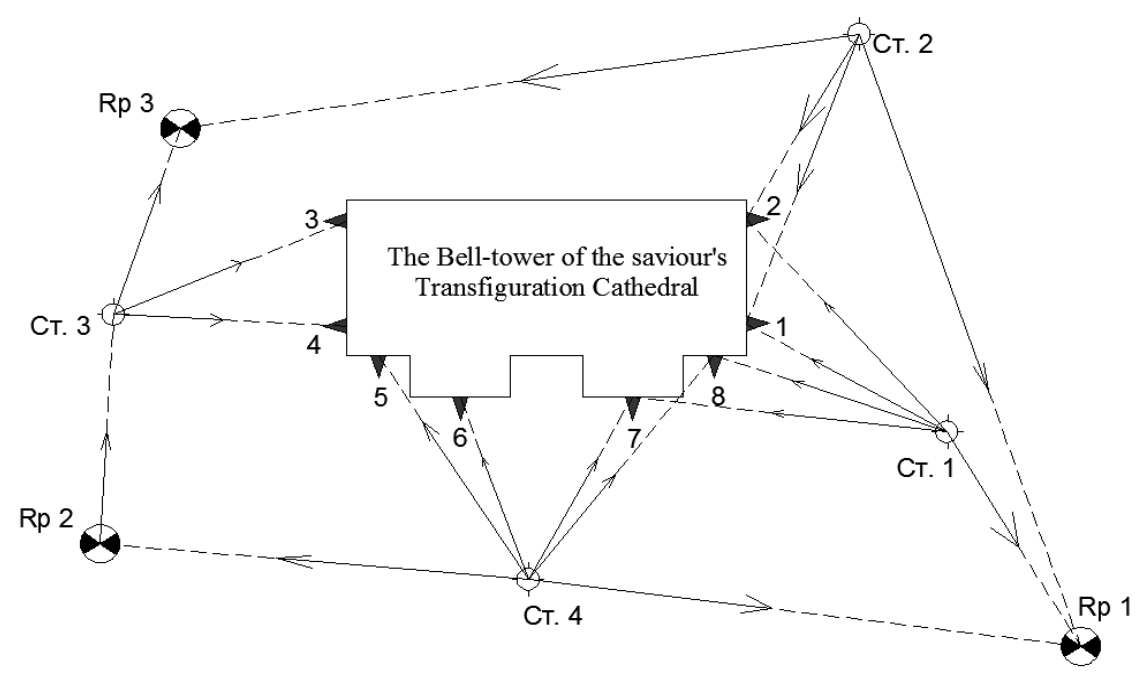

Fig. 13. The diagram of location of lubber lines and stations as related to the bell-tower of the saviour's Transfiguration Cathedral

After performing the leveling, the exceedance values were compared, which were obtained from the forward and backward directions. Divergence between these values didn't exceed $\pm 10 \mathrm{~mm} \sqrt{L}$. In the course of completion, the geometric leveling of the class III, a standard-issue record of exceedances was composed regularly [4, appendix 32].

Before the beginning of measurements, three ground bench marks were fixed on the ground Rp.I, Rp.II, Rp.III, which were tied to the input bench mark line with a known mark of the urban vertical control survey network [3, section 6]. The lubber lines were located aside on passages, underground utility systems, open storages, outside zones of extension of pressure from building and constructions, outside the borders of influence from settlement phenomenon, landslides, slopes, unstabilized mounts at the distance from buildings (constructions) not less than triple wise width of the level of the ground, which settles and at the distance which includes influence of vibration from transport, cars, machines in places where during the entire period of observation an unhampered and comfortable access to the bench mark lines is possible for setting geodetic instruments $[3,5]$. The measurements were performed not earlier than 10 days after setting the signs.

Leveling of deformational benchmarks was performed from four (St.1, St.2, St.3, St.4) constantly fixed stations. When performing the measurements there was no possibility to control inequality of the shoulders (distance to the rod), therefore the method of «a short ray» was applied - the distance to the rod didn't exceed $25 \mathrm{~m}$, the height of the ray from the ground surface didn't exceed $3 \mathrm{~m}$ with farness distance of the rays from surrounding items more than $0.5 \mathrm{~m}$. The average quadratic deviation of geometric leveling at the station along with intrinsic convergence was $0.3-0.5 \mathrm{~mm}[1,5]$.

In the third cycle of the observation, which was performed in two months after their beginning, rapid settlement of all deformation benchmarks was observed, in average approximately by $5.2 \mathrm{~mm}$, at this particular time the building-reconstruction of the main building of the Church was started.

Then an equable settlement was observed from the third till the fourteenth cycle, the benchmarks 2 and 3 were settled by $6.9 \mathrm{~mm}, 4.4 \mathrm{~mm}$ correspondingly. This is happening due to gradual loading during the building-reconstruction of the main building of the Church exactly from the point of the bell-tower where these benchmarks were located.

From the opposite side of the bell-tower another way of settlement was observed, there were the benchmarks 1, 4-8. From the third cycle to the sixth cycle they gradually settle in average by $0.55 \mathrm{~mm}$, and from a the sixth cycle of the observation to the fourteenth cycle a gradual raising of these deformation benchmarks of the base of the footing in average by $1.27 \mathrm{~mm}$ was observed, since a monolithic concrete slab of the bell-tower footing gets an insufficient inclination due to additional loading from the benchmarks 2, 3 during building the main building of the Church (Fig. 14).

The consecution of the settlement of all deformation benchmarks is presented in the Picture 15, which shows inequality of the settlement. A consistent pattern of the rapid settlement of the 
benchmarks 2, 3 in average for the entire period by $7.66 \mathrm{~mm}$ with gradual decreasing, and settlement of the benchmarks $1,4-8$ to the contrary - gradually comes to raising.

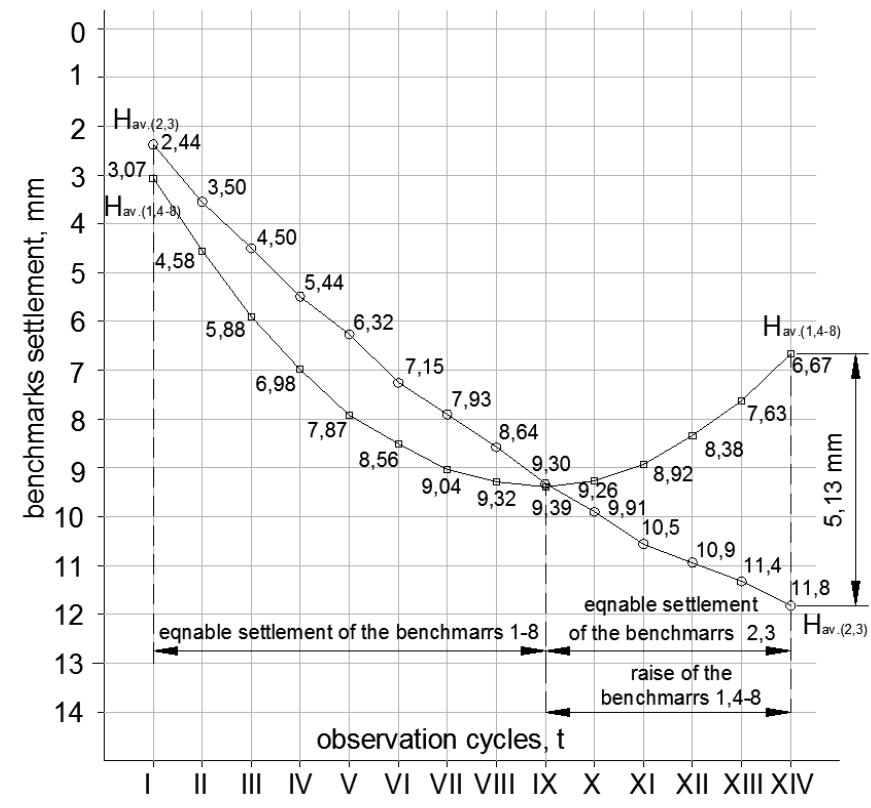

Fig. 14. The assay of experimental and functional dependences $H_{a v}(2,3)$ та $H_{a v}(1,4-8)$

But in the confident conclusion about the progressing or damping character of the deformation benchmarks settlement some statistic consistent patterns were set and graphs of experimental and functional dependences were composed correspondingly (Picture 16-17), which correspond to the quadratic dependence of the type:

$$
\mathrm{H}=\mathrm{at}^{2}+\mathrm{bt}+\mathrm{c}
$$

At considering the numeric value of the parameters $a, b, c$ will be as following:

- for deformation benchmarks 2-3:

$$
\mathrm{H}=-0,02826 \mathrm{t}^{2}+1,14 \mathrm{t}+1,33
$$

- for deformation benchmarks 1, 4-8:

$$
\mathrm{H}=-0,1027 \mathrm{t}^{2}+1,817 \mathrm{t}+1,352,
$$

where $\mathrm{t}-$ time in months as relating to the first cycle of the observations.

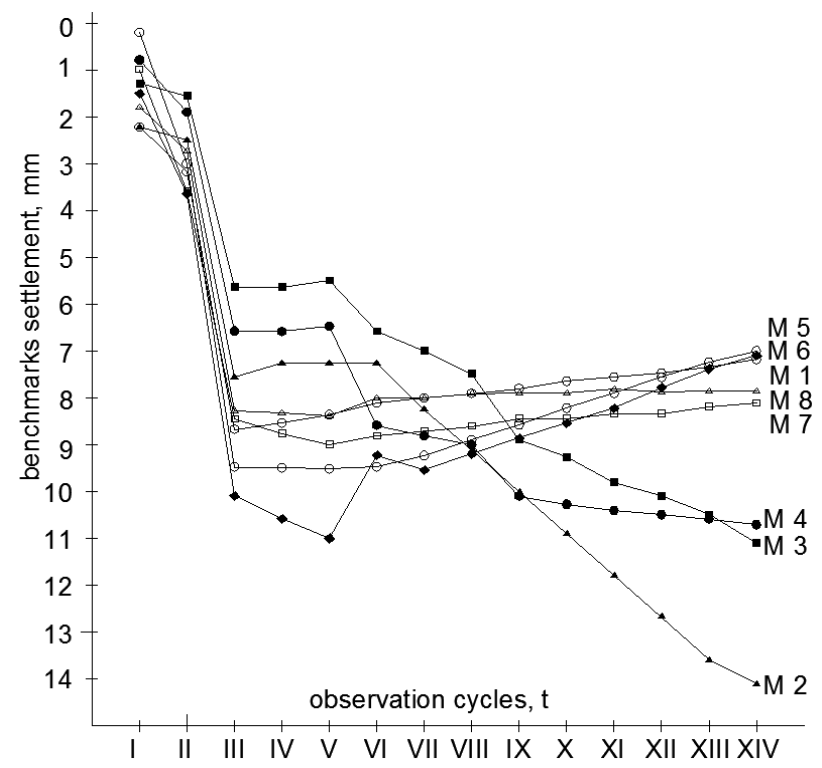

Fig. 15. Settlement progress of eight deformation benchmarks for the period from 9.01.2001 to 10.02.2002 


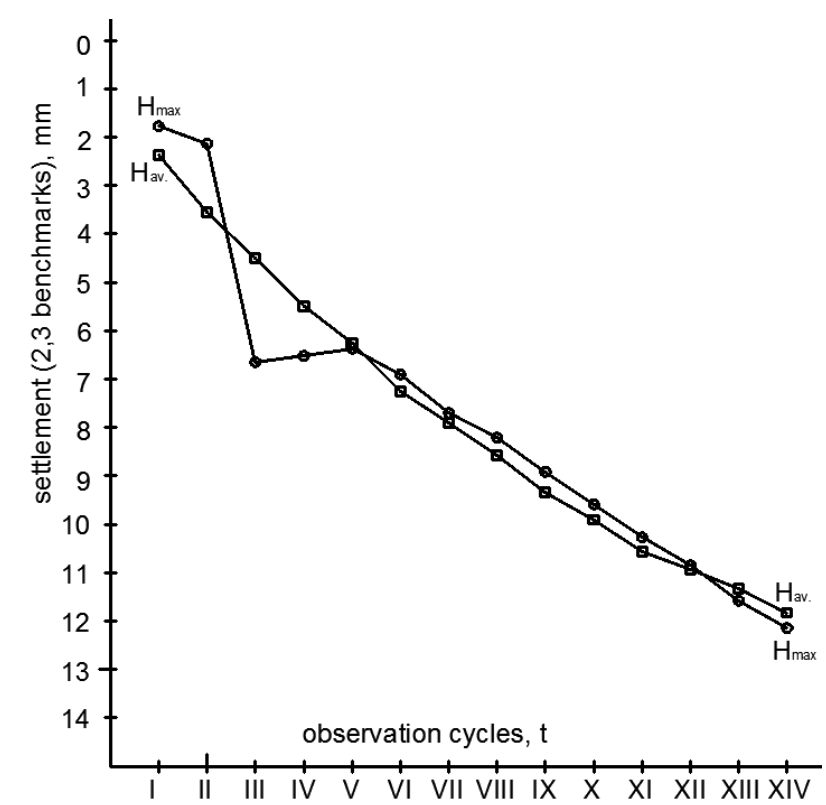

Fig. 16. The graph of experimental and functional dependences of the deformation benchmarks 2,3

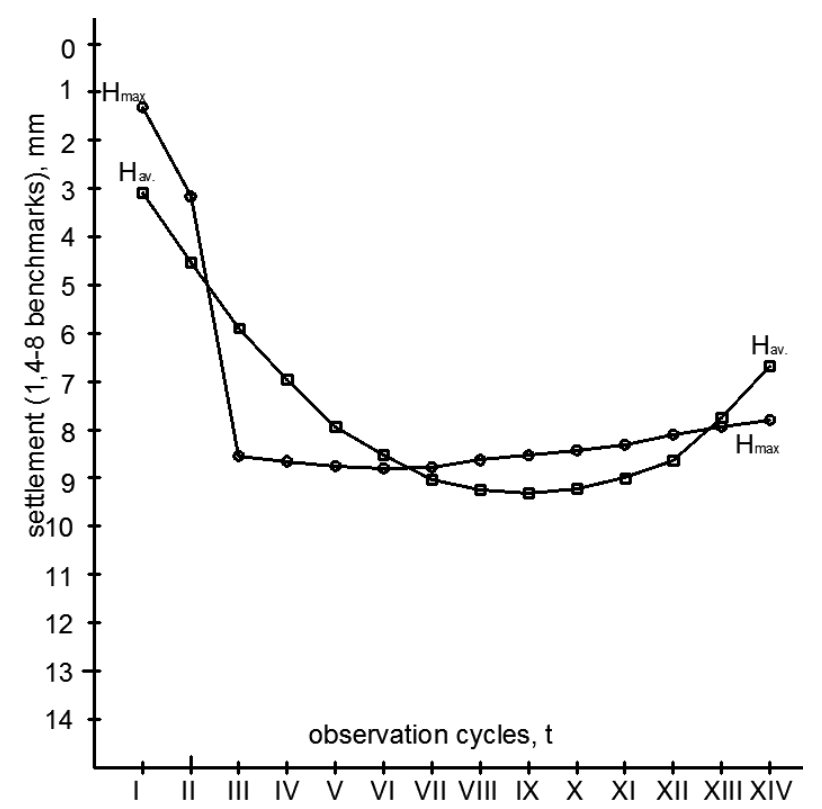

Fig. 17. The graph of the experimental and functional dependences of the benchmarks $1,4-8$

The diagram shows epures of deformation benchmarks settlement as related to the first cycle of the observation (Picture 18). It is visible from this point that maximum settlement of the belltower footing is up to $14,1 \mathrm{~mm}$, and minimum is $-7,0 \mathrm{~mm}[5,7]$.

During the period of the observation over the settlement of the benchmarks building of the main building of the Cathedral was taking place, therefore a gradual loading of the building from the benchmarks 2 and 3 played a significant role in the influence on the settlement.

After forecasting the settlement of the base of the footing of the deformation benchmarks 2,3 it was obtained that after 20,2 months their average settlement will stop, having reached $12,8 \mathrm{~mm}$.

And average raising of the benchmarks 1, 4-8 stabilized and reached 0,1-0,2 mm.

Therefore, providing the saving of the building conditions and in the absence of additional influences a damping is expected and integral equalization of the bell-tower footing base settlement.

Geodetic monitoring during the period of operation the Church proved an accountant forecasting estimate of the damping and integral equalization of the bell-tower footing base settlement.
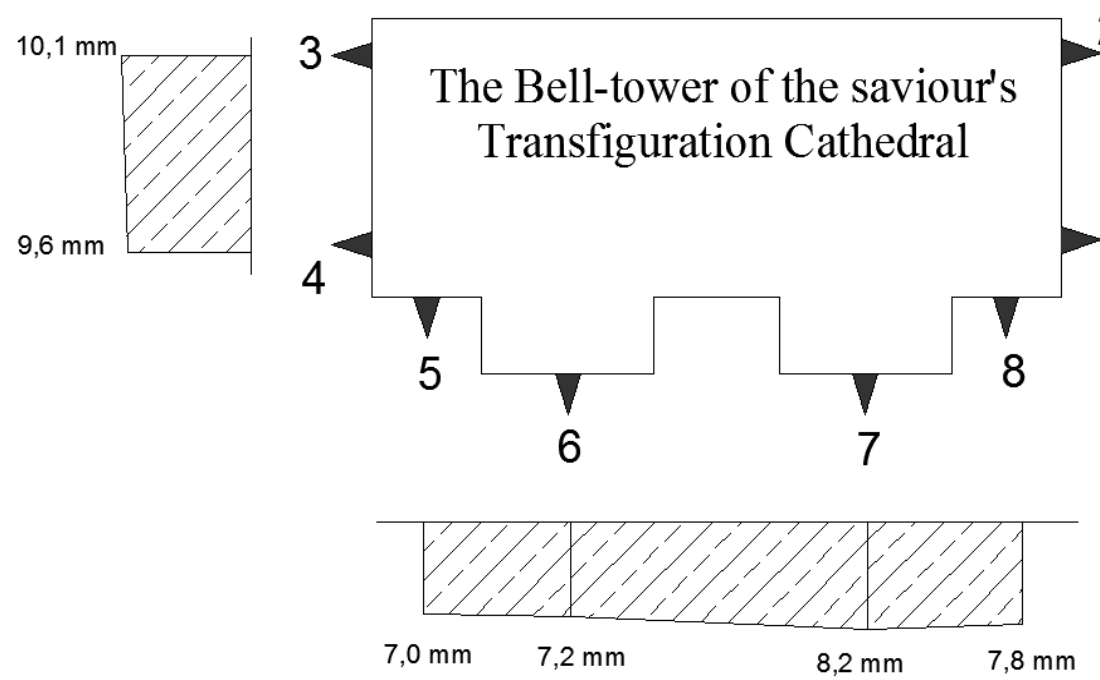

Fig. 18. A diagram of epures of the deformation benchmarks settlement during the entire period of observations, $\mathrm{mm}$ 
On the 19 of January 2002 the first stone was laid into the wall of the upper Churches of the saviour's Transfiguration Cathedral. In 2002 and 2003 the first Church services were held in the lower and upper Churches correspondingly. The completion of the building of the lower Church, saint Andrew's Hall and starting the Church of the saviour's Transfiguration Cathedral took place in the 2005.

Conclusions. Samples of architecture as any other architectural objects, require considerate attention, at times it can be necessary to reconstruct a roof, drainage system, rehabilitation of footing or to perform a global reconstruction. According to experts, officials and public representatives not much care is taken about the problem of architectural landmarks saving. Saving of architectural landmarks has always been at the place among the problems, which are offered to be resolved by those who strive for power. Care about the environment is usually included into the five issues, which politicians promise to resolve, but saving of architectural landmarks is not much interesting for the public, that's why nobody takes it up. There is no demand - there is no proposal.

On the example of the bell-tower of the saviour's Transfiguration Cathedral the authors of this article want to draw attention of the community to this problem. Surely everyone knows that if there is no national history of the country, such country stops its existing. Geodetic monitoring, especially of architectural landmarks, is essential for Odessa also. On this subject, geodetic observations were performed and analyzed, diagrams of settlement of the footing base during building-reconstruction of the main building of the Church were formed. Three bench mark lines were lied in, eight benchmarks were set in the lower part of the front of the bell-tower, which were under observation using the method of geometric leveling of class III.

At the beginning of the building-reconstruction the bell tower was exposed to rapid settlement of the footing base at all set benchmarks during the period from the first to the sixth cycle of observations (3 months). In average, the settlement mark was up to $5.2 \mathrm{~mm}$, at that particular period building-reconstruction of the main building was started.

At gradual loading during the building-reconstruction from the third to the fourteenth cycle equable settlement of the benchmarks 2 and 3 by $6.9 \mathrm{~mm}$ and $4.4 \mathrm{~mm}$ correspondingly was observed.

From the opposite side of the bell-tower another way of settlement was observed, there were benchmarks 1, 4-8, absolutely opposite to the benchmarks 2-3. Starting with the third cycle to the sixth cycle the building gradually settles in average by $0.55 \mathrm{~mm}$ around the entire perimeter, and from the sixth to the fourteenth cycle a gradual raising of these deformation benchmarks of the footing base in average by $1.27 \mathrm{~mm}$ was observed, because from the side of those benchmarks there is no loading and thus the opposite side of a monolithic concrete slab of the bell-tower footing overbalances approximately by $5,13 \mathrm{~mm}$ with an insufficient inclination.

Using the consistent pattern of experimental and functional dependences average settlement of the footing base of deformation benchmarks 2, 3 was forecasted and the result of $12.8 \mathrm{~mm}$ in 20.2 months was obtained.

It can be finally concluded that further investigations of the bell-tower footing settlement during the building (reconstruction) of the main building of the Transfiguration Cathedral which consists of two levels, proved the calculated predictive valuation of damping with gradual loading without absence of additional outer and inner influences, and the theory of forecast of further settlement of deformation benchmarks set around the perimeter of the bell-tower footing base with their complete stabilization was successfully tested.

\section{References}

[1] DBN V.1.3-2:2010 «Geodezyichni roboti u budivnicztvi». Kiyiv, Minregion Ukrayini, 2010.

[2] DBN V.1.3-2:2010 «Sistema zabezpechennya tochnosti geometrichnix parametriv $u$ budivnicztvi. Geodezichni roboti v budivnicztvi». Kiyiv, Minregion Ukrayini, 2018.

[3] DSTU B V.2.1-30:2014 «Grunti. Metodi vimiryuvannya deformacij osnov budinkiv i sporud». Kiïv, Minregion Ukraïni, 2015. 
[4] Instrukciya po nivelirovaniyu I, II, III et IV klassov. Moscow, Nedra, 1974.

[5] Instrukciya z topografichnogo znimannya u masshtabax 1:5000, 1:2000, 1:1000 ta 1:500. Kiyiv, GKNTA-2.04-02-98.

[6] «Kirxa - istoriya spaseniya», Naukometrichnij zhurnal «Nauchnыj vzglyad v budushhee!», Germaniya Mizhnarodne periodichne vidannya «International periodic scientific journal», Vipusk 5, Tom 2, 2018.

[7] Rukovodstvo pro nablyudeniam za deformaciamy osnovanij $i$ fundamentov zdanij $i$ sooruzhenij. Moskva, Strojizdat, 1975.

\title{
ГЕОДЕЗИЧНИЙ МОНІТОРИНГ ПІД ЧАС ВІДБУ ДОВИ ХРАМУ
}

\author{
Захарчук В.В., ст. викладач, \\ tzvvxxx@gmail.com, ORCID: 0000-0002-0370-4113 \\ Третенков В.М., к.т.н., професор, \\ Шишкалова Н.Ю., ст. викладач, \\ Shishkalova7@gmail.com \\ Одеська державна академія будівництва та архітектури
}

\begin{abstract}
Анотація. При будівництві та реконструкції об'єктів нерухомості, а особливо пам’яток архітектури, необхідно проводити геодезичний моніторинг. Це спостереження за деформаціями будівель під час будівельного процесу. Такий моніторинг дозволяє визначити причини утворення відхилень від проектних та зазирнути наперед прогнозуючи їх розвиток, а також надати рекомендації для відповідних заходів, щоб не допустити критичних ситуацій, які можуть призвести до непоправних наслідків.

Hi для кого не секрет, що нова будівля після закінчення будівництва протягом певного часу дає осадку. Це явище пов'язане з тим, що грунт ущільняється під вагою побудованого будинку, тому осадка об'єкта нерухомості вважається цілком нормальним процесом.

Геодезичний моніторинг за осіданням основ фундаменту дзвіниці СпасоПреображенського собору починається із геометричного нівелювання відповідного класу точності за допомогою нівеліру Н3 та шашкових рейок. Перед виконанням геодезичних робіт нівелір та шашкові рейки проходили перевірку для встановлення їх придатності до даного виду робіт. Геометричне нівелювання виконувалось в прямому і зворотному напрямках із обов'язковим контролем спостережень на кожній станції.

На місцевості закріплено три грунтових репера, що прив'язувались до вихідного репера із відомою відміткою міської мережі. Вимірювання проводились не раніше 10 днів після закладки знаків.

По периметру основи фундаменту дзвіниці закріплено вісім деформаційних марок. Нівелювання цих марок проводилось із чотирьох станцій, що також прив'язувались до закріплених попередньо реперів. Результати спостережень фіксувались відповідно чотирнадцяти циклів. Інтервал між циклами спостережень відповідає одному місяцю.

Основна робота була направлена на дослідження прогнозування осідання деформаційних марок за допомогою статистичної закономірності із складанням графіків експериментальних та функційних залежностей, що відповідають квадратичній залежності виду $\mathrm{H}=\mathrm{at}^{2}+\mathrm{bt}+\mathrm{c}$.

Ключові слова: геодезичний моніторинг, деформаційні марки, геометричне нівелювання, осідання фундаменту, цикли спостережень, репер, експериментальні та функційні залежності, прогноз осідання фундаменту дзвіниці.
\end{abstract}




\title{
ГЕОДЕЗИЧЕСКИЙ МОНИТОРИНГ ПРИ ВОССТАНОВЛЕНИИ ХРАМА
}

\author{
Захарчук В.В., ст. преподаватель, \\ tzvvxxx@gmail.com, ORCID:0000-0002-0370-4113
}

Третенков В.М., к.т.н., профессор, Шишкалова Н.Е., ст. преподаватель, Shishkalova7@gmail.com

Одесская государственная академия строительства и архитектуры

\begin{abstract}
Аннотация. При строительстве и реконструкции объектов недвижимости, а особенно памятников архитектуры, необходимо проводить геодезический мониторинг. Это наблюдения за деформациями зданий во время строительного процесса. Такой мониторинг позволяет определить причины образования отклонений от проектных и заглянуть вперед, прогнозируя их развитие, а также предоставить рекомендации и соответствующие меры, чтобы не допустить критических ситуаций, которые могут привести к непоправимым последствиям.

Ни для кого не секрет, что новое здание после окончания строительства в течение определенного времени дает осадку. Это явление связано с тем, что почва уплотняется под тяжестью построенного дома, поэтому осадка объекта недвижимости считается вполне нормальным процессом.

Геодезический мониторинг за осадками оснований фундамента колокольни СпасоПреображенского собора начинается с геометрического нивелирования соответствующего класса точности с помощью нивелира Н3 и шашечных реек. Перед выполнением геодезических работ, нивелир и шашечные рейки проходили проверку для установления их пригодности к данному виду работ. Геометрическое нивелирование выполнялось в прямом и обратном направлениях с обязательным контролем наблюдений на каждой станции.

На территории закреплены три грунтовых рэпера с привязкой к исходному реперу известной отметкой городской сети. Измерения проводились не ранее 10 дней после закладки знаков.

По периметру основания фундамента колокольни закреплено восемь деформационных марок. Нивелирования этих марок проводилось из четырех станций, также привязывались к закрепленным предварительно рэперам. Результаты наблюдений фиксировались в соответствии четырнадцати циклов. Интервал между циклами наблюдений соответствует одному месяцу.

Основная работа была направлена на исследование прогнозирования осадки деформационных марок с помощью статистической закономерности с составлением графиков экспериментальных и функциональных зависимостей, соответствующие квадратичной зависимости вида $\mathrm{H}=\mathrm{at} 2+\mathrm{bt}+\mathrm{c}$.

Ключевые слова: геодезический мониторинг, деформационные марки, геометрическое нивелирование, осадки фундамента, циклы наблюдений, рэпер, экспериментальные и функциональные зависимости, прогноз оседания фундамента колокольни.
\end{abstract}

Стаття надійшла 6.05.2019 